\title{
UNIVERSITY OF SOUTH FLORIDA CREDIT UNION AND USF COLLEGE OF BUSINESS: MARSHALL CENTER BRANCH
}

Rick Skaggs was once again recently reminded of the Pogo saying... "We are surrounded by insurmountable opportunities." Sometimes it certainly felt like that. Rick was not complaining about having too many prospects, he was just examining the "opportunities" within the context of available resources and other opportunities. For over three years now, Rick Skaggs has been President and CEO of the USF Federal Credit Union. Yet, Rick was recently presented with another endeavor. The dean of the College of Business at the University of South Florida, Dr. Moez Limayem, had approached Mr. Skaggs with a proposition involving students enrolled in the college. Dr. Limayem proposed that a branch of the USF Federal Credit Union, currently located on campus at the student Marshall Center, be operated and managed by students from the college of business. The dean viewed this relationship as a potential showcase for the college of business and also indicated he would like this to happen as soon as possible.

Rick knew this had been done at other Universities and yet he also knew there would be numerous considerations for accomplishing this endeavor at USF. Regardless, he saw this as a potential win-win. He believed there could be several advantages for the credit union as well as for the students who become integrated, educated, and trained in the financial practices of the credit union. He had already reflected on potential impacts to existing employees, training issues, recruiting opportunities, new models for student/personnel development yet was concerned about moving too quickly. There were many decisions to be made during the plan to move forward.

Some of the decisions would revolve around training issues. Just how would the training be organized? Would training/education be shared between the college of business and the credit union? What role must the credit union take and what could be done in the business college? Rick recognized that there would likely be privacy concerns. How would the credit union convince stakeholders that students would not present privacy concerns? Other questions arose regarding evaluation of just how successful this joint venture would be. The dean expressed the desire to show increased operational efficiencies at the Credit Union with college of business students. What would be the actual measures of success for the college of

This case was prepared for the purpose of class discussion, and not to illustrate the effective or ineffective handling of an administrative or classroom situation and is copyrighted by the Informing Science Institute. Permission to make digital or paper copy of part or all of these works for personal or classroom use is granted without fee provided that the copies are not made or distributed for profit or commercial advantage AND that copies 1) bear this notice in full and 2) give the full citation on the first page. It is permissible to abstract these works so long as credit is given. To copy in all other cases or to republish or to post on a server or to redistribute to lists requires specific permission and payment of a fee. Contact Publisher@InformingScience.org to request redistribution permission. business and the USF federal credit union?

Would a new model for member service representative / teller be a viable alternative for the future student manned/managed branch?

Rick was cautiously optimistic that all of the challenges would become opportunities for the USF Federal Credit Union and the College of Business and the University of South Florida. 


\section{Brief History of Credit Unions ${ }^{1}$}

The credit union movement originated with the idea that members of a community could increase their standard of living by pooling their financial resources and making loans to their neighbors and coworkers. Credit unions are basically community-based banks that operate as a cooperative. Functioning as a cooperative, credit unions are member owned and are operated for the benefit of its members.

The first credit unions originated in Germany about 1849 to find alternatives to various loan sharks of the day. The credit union cooperatives were founded to assist the working class in their efforts to gain better financial services. It was estimated that by 1913, 2 million Germans were members of credit unions, most of which were in rural areas with communities of less than 3000 people. The movement defied opponents who argued that poor Germans would not repay their loans.

The first Credit Union in the United States was established in 1909 in Manchester, New Hampshire. In 1921, the Credit Union National Extension Bureau was organized to enact credit union laws and form credit unions. President Franklin D. Roosevelt signed the Federal Credit Union Act into law in 1921 to enable federally chartered credit unions in all states. It was not until 1970 that the National Credit Union Administration (NCUA) was formed to charter, supervise, and insure credit union deposits through the National Credit Union Share Insurance Fund (NCUSIF). The NCUSIF is administered by the NCUA and is entirely funded by participating credit unions.

Being member-owned and not required to generate profits for shareholders, many banks complained that credit unions had an unfair competitive advantage. In 1996, The District of Columbia Federal Appeals Court issued an injunction prohibiting federal credit unions from extending their membership beyond the original core membership group. During President Clinton's administration, the Credit Union Membership Access Act was signed into law in 1998. This act further defined the fiscal responsibilities of federal credit unions and the definition of membership formation.

Serving a clearly defined group of members - who were both customers and owners - credit unions were able to provide a portfolio of services tightly focused on member needs. These included asset-based loans (e.g., car loans and mortgages), credit cards, interest-bearing savings and money-market accounts and nofee or low-fee checking accounts. Because most credit unions were local, they tended to provide hightouch service out of local offices, rather than moving rapidly to Internet-based banking. They were, however, generally able to achieve a national presence through reciprocal relationships with other local credit unions.

\section{The USF Federal Credit Union}

USF Federal Credit Union was chartered in 1959 to serve the financial needs of the staff and faculty at the University of South Florida. It became a Federal Credit Union, regulated and insured by the National Credit Union Administration (NCUA) in 1985. The field of membership expanded to include students in 1990. The Credit Union was located in various University-provided locations until 1972, when the State of Florida leased land to USF Federal Credit Union to build a permanent facility of approximately 3,000 square feet. The main office enlarged in 1981, 1985, and 1997, bringing the total office space to 24,000 square feet. By 2014 USF Federal Credit Union had over 36,000 members with assets of over $\$ 430,000,000$.

The mission statement of the USF-FCU is as follows:

\footnotetext{
${ }^{1}$ The following two sections are substantially derived from the previously published: Will, R. \& Skaggs, R. (2013). USF Federal Credit Union. Journal of IT Education: Discussion Cases, 2(1), 1-22.
} 
Our Credit Union is a financial institution owned and controlled by Members for their benefit that:

- Delivers superior service in a friendly and courteous manner with respect for the worth and dignity of all its members

- Promotes thrift and the cooperative ideals of the credit union philosophy

- Offers loans and deposit accounts at competitive rates and high quality financial services at fair prices for users of those services

- Maintains long-term financial stability to insure security of member deposits

- Is a responsible member of the University community

USF Federal Credit Union had performed relatively well during the challenging national and global financial crisis from 2008-2012. Key financial indicator trends and growth trends were important to assess the long-term performance of financial institutions, including credit unions. Some key indicators with data through December 2013, shown in Exhibit 1, included comparisons of USF-FCU with their peer group and with the national average. The peer group consisted of those credit unions with approximately the same asset level. Specifically:

- Net Worth Ratio. This indicated the stability of the credit union. Typically, larger was better. National averages were around 10 percent. If assets grew and Capital did not grow proportionally, then this ratio would decline.

- Return on Average Assets (ROAA). The ROAA measured net worth in relation to average assets, representing the bottom line. A positive ratio would indicate that earnings covered operating expenses and cost of funds. ROAA was calculated as Net Income (loss) [with the option of excluding Temporary Corporate Credit Union Stabilization Income/Expense and NCUSIF Premium Expense] divided by average assets. The presence of a Stabilization Expense in the Exhibit 1 ROAA graph should be readily apparent.

- Operating Expenses as Percentage of Average Assets. OEPAA was an indicator of cost control. Obviously, the lower the percentage, the more efficiently the company appeared to be performing.

- Annualized Rate of Growth. An indicator of how quickly credit union assets were growing. The "annualization" refers to the fact that the growth rate is averaged over the course of a year.

- Provision for Loan Losses (as a percentage of Average Assets). Refers to the expense that is set aside for potential losses on loans. The credit union reserved funds to cover estimated future losses, with higher percentages indicating that the perceived risk of the loan portfolio was higher.

- Quarterly Membership Growth (Annualized). Benchmarks the percentage change in membership growth from period to period against peer and national averages.

\section{Senior Management at USF Federal Credit Union}

As a member-serving organization, the management and governance structure of the USF-FCU was complex, meeting the needs of various stakeholders.

The Senior Management Team consists of those employees charged with running the operations of the organization. The team is presented in Exhibit 2. In the two years leading up to early 2012, the Senior management team at USF-FCU had experienced significant changes. Among the key officers:

- Rick Skaggs, President/CEO joined the credit union in September, 2010.

- Miles Strickland, Chief Financial Officer - CFO, had joined the credit union in October, 2011, replacing the retiring $\mathrm{CFO}$ of several years. 
- The Senior Vice President, Bruce Koehler had been with the credit union for 25 years.

- Deborah Clark joined the credit union as the Vice President of Marketing and Business Development in April, 2013, to fill a void in that area.

- Gary Wahlgren, joined the credit union in June, 2013, to fill the newly created position of Assistant Vice President of Consumer Lending.

\section{The Student Branch Proposal}

One might refer to Dean Moez Limayem as the source, the impetus, the instigator, or just patient zero for the idea behind a College of Business student run branch of the USF Federal Credit Union. In December 2013, Dean Limayem convened a meeting with senior management of the USF-FCU in order to advance a novel proposal: that the Marshal Center Branch of the credit union be transformed into an operation run entirely by students.

\section{Moez Limayem}

Moez Limayem joined the University of South Florida as dean of the College of Business in 2012. He was formerly with the Sam M. Walton College of Business at the University of Arkansas, where he served simultaneously as the associate dean for research and graduate programs, the executive director of the Information Technology Research Institute and the Radio Frequency Identification Center, and the Edwin \& Karlee Bradberry Chair in Information Systems.

Limayem worked in the private sector as a systems analyst and computing consultant before receiving his MBA and PhD in business administration from the University of Minnesota. Since 1992, he has served as an international expert in IT for UNESCO. He has taught at universities across the globe, including the University of Minnesota, Laval University in Canada, City University of Hong Kong, and Lausanne University in Switzerland, as well as the University of Arkansas.

Limayem speaks of the role the College of Business plays in the community as providing more than dissemination of information. Limayem states that the college creates intellectual capital and produces graduates who are not only ready for today's workplace, but who are also trained to be forerunners in tomorrow's workforce. In short, we equip students with the skills and knowledge needed to take leadership positions in business and society. He also illustrates that the college of business students participate in internships, case competitions, and professional mentoring and networking opportunities impossible at many other business schools.

\section{The Proposal}

The proposal for a College of Business student run and managed branch of the USF FCU was inspired by what Dean Moez Limayem referred to as the strategic priorities of the College. He cited that student success is at the core of those strategic priorities and the heart of what we do. The emphasis is on helping students retain employment when they graduate. He stated that 96 percent of student's with internships or other relevant experiences simply get jobs at graduation. This venture with USF FCU is viewed by Limayem as a win-win scenario for bringing student talent to the credit union and an incredibly rich experience to the students involved in the process.

Limayem stressed the investment and commitment to the students. He sees this as being on the leading edge of providing students with real and challenging experiences while providing the USF-FCU with outstanding talent for achieving high performance expectations. His expectations include higher levels of performance from the student managed branch, including areas of service, marketing, member satisfaction, etc. 


\section{Perspectives of Senior Management}

During a series of interviews, a variety of different perspectives on the possible student-run branch project surfaced. Summaries of these follow.

\section{Bruce Koehler, Senior Vice President}

Bruce Koehler discussed openly an initial vision for the possibility of a student run branch at the USF Marshal center. He presented a phased approach that included student involvement in their sophomore, junior, and senior years at the University of South Florida. As a sophomore, the student would be located at the main office of the USF Federal Credit Union and would be engaged in training that would include exposure to various job functions on a rotating basis. During the junior year, the participating student would be working in a specific credit union department while shadowing current employees. Finally, during the student's senior year, s/he would be an active employee at the Marshal Center branch.

Bruce Koehler saw a challenge with the full time demands of the student and the center. The branch must be open during normal working hours, and the student's schedule could likely contain courses during those hours. He suggested looking into a possible tag-team approach where some students would work in the morning while others worked in the afternoon.

Koehler also saw a benefit for the student engaged in the process through extensive experience in the service sector of the financial world. In addition he suggested that a supervisory committee, from existing credit union management, be established. It was also proposed that a student advisory committee be set up with a blend of expertise to give feedback and suggestions for ideas to improve service and performance at the credit union. He also mentioned that we would need input from many people within the credit union.

The staffing positions for the Marshal Center branch would ideally include five to six positions. There would be two tellers, one senior teller, one member services representative (msr), one account manager, and one branch manager. Bruce Koehler also questioned if the branch would be both manned and managed by students, concluding that it would likely need to be both. Bruce Koehler mentioned that timelines for training would need to be established and specific goals for each type of training established. A potential timeline suggested for teller training included at least one full time month of education and training followed by one full month of on-the-job shadowing and two additional months to complete the teller training.

Since students would be performing all typical financial transactions, any student working at the credit union would have access to financial records of faculty maintaining accounts. Students would necessarily be held to the same standards of privacy and financial regulations. Training has been typically done by position, and the same is expected for any students hired for the branch at the Marshal Center. He also suggested that training plans be established with potential course work and that cross training occur so that students could "backfill" other positions when needed.

\section{Miles Strickland, CFO; and Deborah Clark, Vice President Marketing / Busi- ness Development}

One of the first comments Mr. Miles Strickland made regarding the student managed branch at the Marshall Center was "what an awesome opportunity." Strickland also initially mentioned the idea of internships where students could work at the main branch first and then become tellers at the Marshal Center branch. He estimated that it would take three to four part-time students to fill one role (teller, member service representative, manager). Strickland expressed a need for a personnel person to coordinate the 
potential staffing issues associated with several people filling one position. Lending authority, he said, may be one of the eventual challenges.

Strickland indicated that the credit union would need to build and continue to refine a business model along with hinting that it may represent a business within a business. Since students would obviously think like students, he was optimistic that students would be able to provide some potential help with strategic marketing perspectives. Strickland suggested that the credit union play on the strengths of the students (i.e., their majors, interests, previous experiences, and background) for selection and particularly placement.

Mr. Strickland also expressed the need to attract students, possibly as freshmen, and retain them after they have been trained. Miles indicated that this would likely be a three to five year plan. He also indicated that there may be the possibility of two teams working on competitive projects where the "winning" team would have the opportunity to deploy their project. The following year could involve yet another project or projects.

Debbie Clark indicated the above "projects" could be part of a brainstorming process. Even though the projects created may possibly be overwhelming to implement, they could possibly lead to strategic initiatives. She also indicated that it would be helpful for all of the students to gain an operational perspective of how "it all works." Students should know the intricacies of financial institutions and learn what opportunities are available in the financial community.

Strickland also expressed the need for a separate committee to add strategic value. For example students could reflect on the information technology capabilities at the credit union. The IT staff was targeting a 99.99\% uptime rate for the credit union network. He indicated that a student with the appropriate background could investigate and potentially elaborate on the issues leading to the infrastructure necessary to achieve that desirable reliability. Eventually, this could also include a development environment to create applications for use with the Symitar computing environment.

Clark supplemented the above from Strickland by adding that students might be able to determine just how we might be able to develop the above. She also mentioned that whatever was done should be the "best in class." The students involved in this process could actually help the USF credit union to differentiate itself from others.

Clark then provided some additional information on universities with student involvement in university credit unions. The information is provided in Exhibit 3.

\section{Gary Wahlgren, Assistant Vice President of Consumer Lending}

Gary Wahlgren shed some perspective on the progression of promotions within the USF Federal Credit Union environment. During the 1970's, he mentioned, there were many more mid-level management positions within the industry and there were still few people that moved from Teller to Management positions. He also questioned just how we would be able to attract students to get involved in the process/program and what measures should be taken to retain students throughout their tenure at USF. There would need to be a steady pool of students (approximately 15-20 each year) employable at the Marshall Center branch.

Wahlgren indicated that it could take up to one year to train someone to become a productive member of the credit union staff. He mentioned training in the areas of $\mathrm{ACH}$, Debit, Check, and Preauthorization transaction processing. One of the questions he posed was just how the training should proceed. He indicated that the USF Federal Credit Union historically focused formal training on teller and new account 
operational functions and is expanding training to a universal concept which will offer an accelerating training module in many areas.

Training would be an ongoing and challenging requirement for both students and management. There would need to be specific knowledge in areas such as banking regulations, operations in the banking industry, Bank Secrecy Act (BSA), Suspicious Activity Reports (SARs), etc. Wahlgren anticipated about 25 different modules for training that would need to be applied to all credit union employees, including the students manning and managing the branch at the USF Marshal Center. The format for the training would need to be determined.

Wahlgren also said that a decision should be made with regard to who would be responsible for which training. What extent would this be the sole responsibility of the credit union? What extent would the College of Business be involved in the training/education? Would there be any University involvement in overall financial literacy? Would this be limited to College of Business students? Would there be opportunities for students with different backgrounds and how would that impact hiring?

Wahlgren saw the alignment as a way for young people to communicate with young people. He also wondered if this endeavor would help eliminate the "churn" associated with employment for credit union employees. Regardless, there would need to be other measures of efficiency, effectiveness, training outcomes, along with the definition of what the College of Business is attempting to accomplish and whether and/or to what extent those goals were accomplished.

\section{The Decisions}

From his own perspective, Skaggs maintained his cautious optimism when discussing some of the detailed issues associated with a student run and managed USF Federal Credit Union branch at the Marshal Center. He expressed that one of the first concerns he would need to address would be the apprehensions of existing credit union staff at the Marshal Center. He felt they would be worried about what would happen to their positions within the credit union. Skaggs also knew that there would be issues with liability, bonding, and of course regulatory issues. Although those issues would be the same for any credit union employee, he surmised that some concern may arise from faculty and staff at the university regarding the disclosure of their financial information to students. Just how comfortable would a faculty member be in giving a "C" to someone who manages their money?

Rick Skaggs spoke about the need for job enrichment in the positions available. For example, he said, everyone will not be a branch manager in a year. Skaggs indicated that another type of position might be more feasible, with a broader role requiring cross training. It may be possible to have a "Universal Representative" rather than just a teller role or just a member services representative role. The new role would participate in many functions, including opening accounts and even making loans.

All of the student functions would require some oversight for a period of time. Skaggs felt it was important to have employed students involved in an advisory board for the Marshal Center. This would not be a governing board, but would advise the credit union on issues regarding business development opportunities within the university. Skaggs also stressed the importance of having a faculty advisor involved in the entire process. There should be a relationship between the branch and the main office (just as there is now).

Skaggs recognized that there were three sets of stakeholders for this project. The College of Business, the USF Federal Credit Union, and central to credit union philosophy, the Credit Union Members. Assuming that the project goes forward or at least determining if it should go forward, several decisions would have to be made, including the following. 
How should the training be organized? The training for each student would necessarily be consistent with the training any employee would undertake at the USF-FCU credit union. Since students would be taking classes, the scheduling may have to be modified to address the student's time constraints.

What training would be allocated to the Credit Union and to the College of Business? (i.e., would the Credit Union be solely responsible for the education and training of the students or could the College of Business offer relevant "banking" courses to assist with some of the education/training requirements?)

How would one go about convincing credit union members that students will not impact privacy concerns? This could include perception issues of specific credit union members. (i.e., would a faculty member feel comfortable discussing financial matters with a student who was given a " $\mathrm{C}$ " in class? - not that a "C" student would be asked to participate in the internship.)

Would the model of cross training personnel provide desired effects (job enrichment, retention, etc.)? Cross training refers to the training of credit union employees (students) in multiple job roles (teller, member service representative, marketing, management).

What should be the measures of success for the College of Business; for the Credit Union? These measures have yet to be discussed in any detail but could include items such as member satisfaction, resolution of member issues (timing, appropriateness), and member servicing efficiencies.

Would the joint venture achieve a better understanding of the student credit union member? Will students be able to relate to other students in an effective manner? 


\section{Exhibit 1: USF Federal Credit Union Key Indicators}
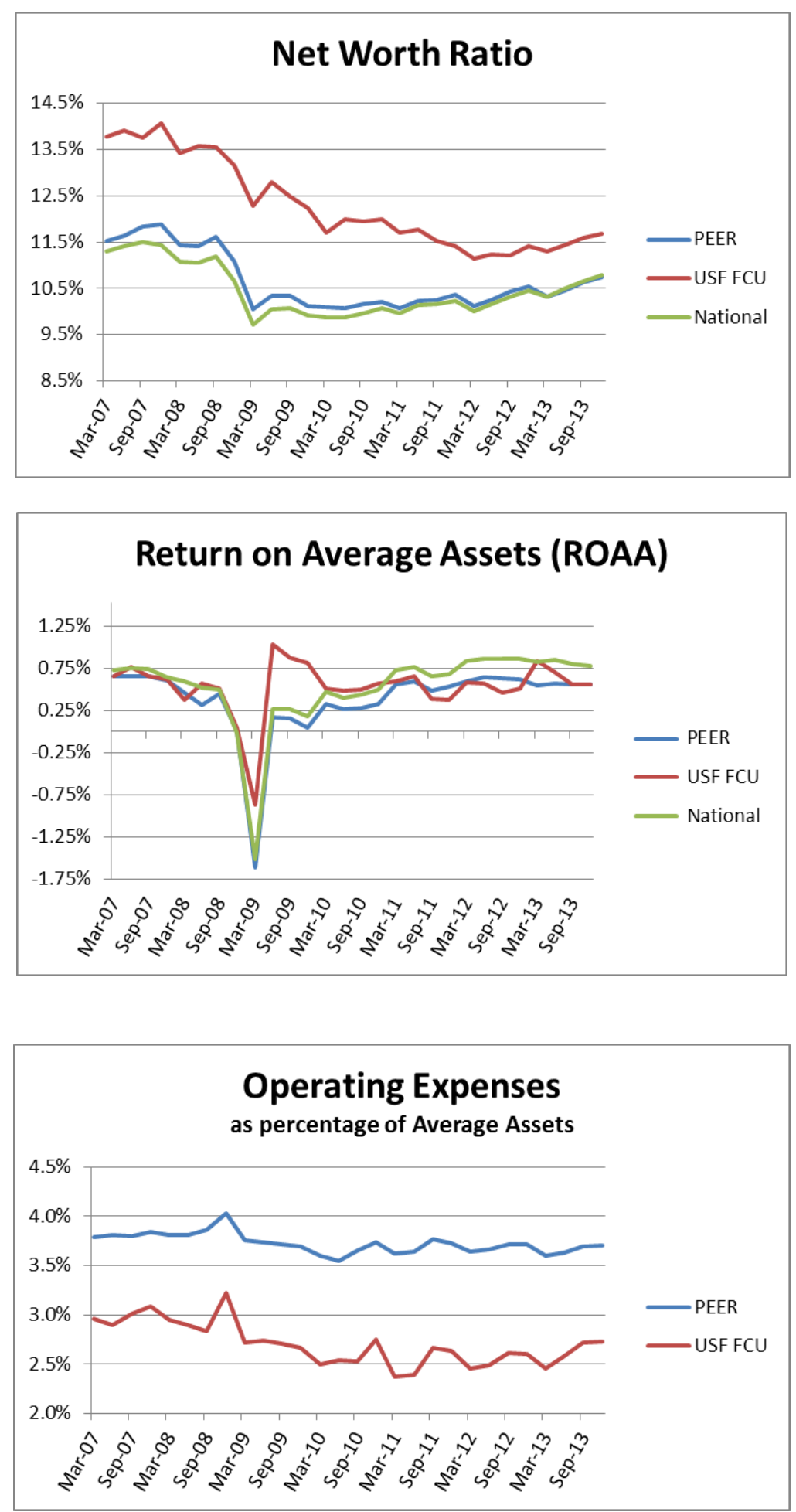

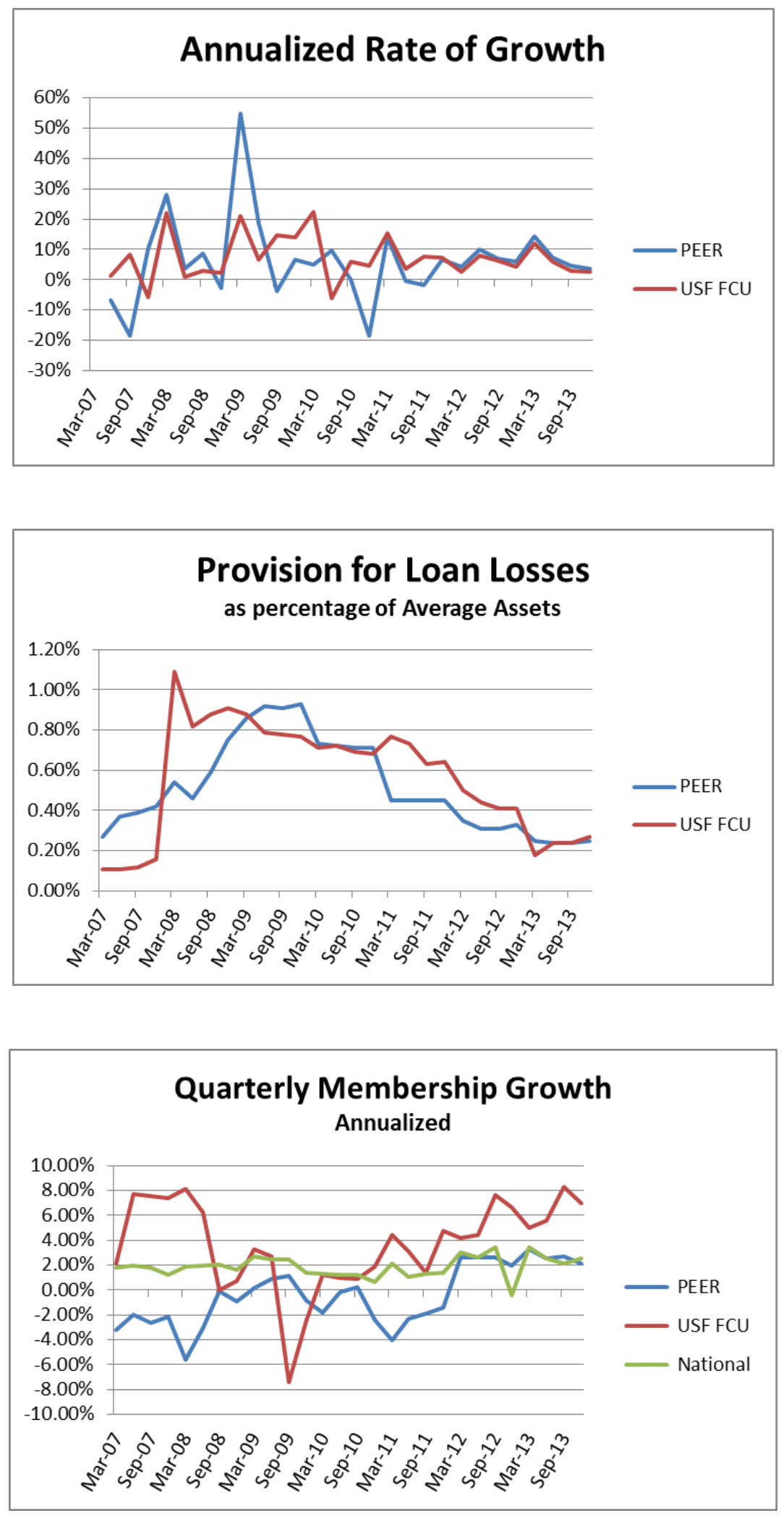


\section{Exhibit 2: USF Federal Credit Union Senior Management Team}

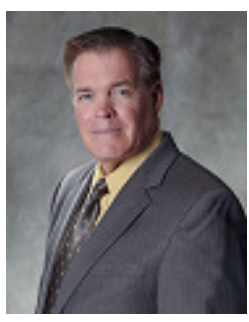

Richard Skaggs,

President/CEO

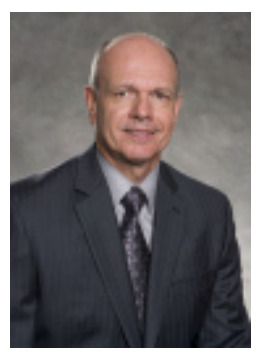

Bruce Koehler, Senior Vice President

Deborah Clark, VP of Marketing/

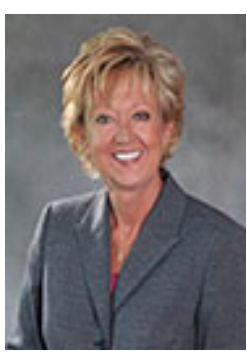
Business Development

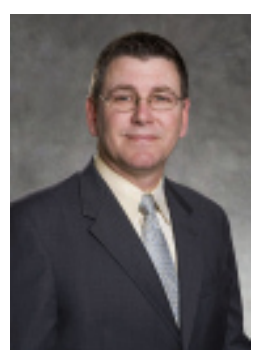

Miles Strickland, Chief Financial Officer

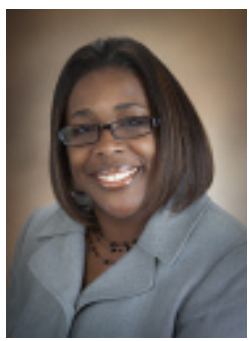

Cheryl Brown, Vice President of Talent

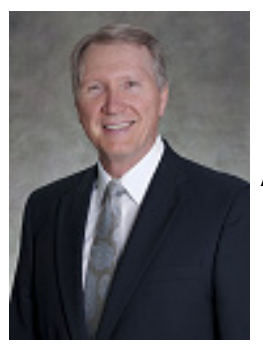

Gary Wahlgren, Assistant Vice President of Consumer Lending

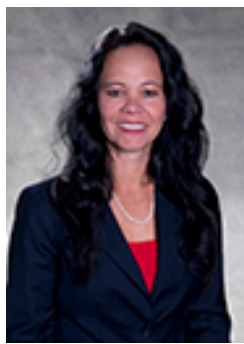

Mary Jane Neusaenger, Assistant Vice President/ Controller 


\section{Exhibit 3: Student Run University Credit Unions (nerd wallet)}

\section{University of South Carolina - Carolina Collegiate Federal Credit Union:}

The University of South Carolina - Carolina Collegiate Federal Credit Union opened their first studentrun branch. The branch operates from 9am to 9pm at the Russell House. The branch is manned by students from all disciplines and has GA's from the College of Hospitality, Retail, and Sports Management.

\section{University of Pennsylvania - Student Federal Credit Union:}

Three Wharton MBA students began the Student Federal Credit Union at the University of Pennsylvania. It is currently one of the largest student student-run credit unions in the nation.

\section{Miami University - First Miami Credit Union:}

This credit union was created by three former students in partnership with the university's Chief Financial Officer. Student interns complete a 5 week course and start in the credit union as tellers. Their credit union provides financial literacy through their "Students for Good Credit program."

\section{Northeast Wisconsin Technical College - Fox Communities Credit Union}

This credit union has a student-run branch at Northeast Wisconsin Technical College. They too have special financial literacy seminars and presentations for fellow students.

\section{Georgetown University Alumni and Student Federal Credit Union}

This credit union has the distinction of being the largest student-run credit union in the world. All student employees of the credit union start out as tellers working shifts as schedules permit. Some will move up to core positions in the organization. The credit union is located in the Leavey Center on campus. 